SAND 79-2036

MASE

\title{
AQUEOUS FOAM SURFACTANTS FOR GEOTHERMAL DRILLING FLUIDS: I. SCREENING
}

P. B. Rand -5813

0. J. Montoya - 5813

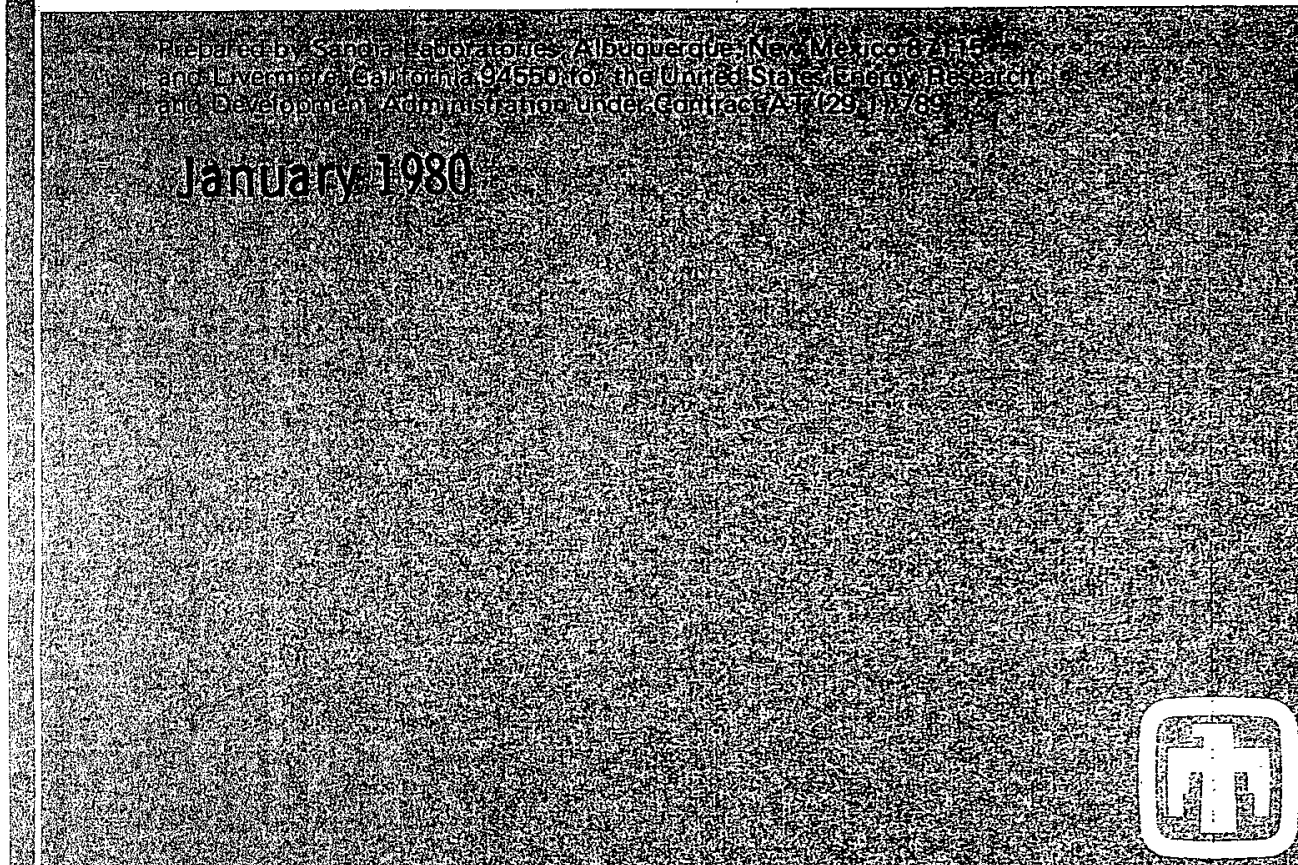




\section{DISCLAIMER}

This report was prepared as an account of work sponsored by an agency of the United States Government. Neither the United States Government nor any agency Thereof, nor any of their employees, makes any warranty, express or implied, or assumes any legal liability or responsibility for the accuracy, completeness, or usefulness of any information, apparatus, product, or process disclosed, or represents that its use would not infringe privately owned rights. Reference herein to any specific commercial product, process, or service by trade name, trademark, manufacturer, or otherwise does not necessarily constitute or imply its endorsement, recommendation, or favoring by the United States Government or any agency thereof. The views and opinions of authors expressed herein do not necessarily state or reflect those of the United States Government or any agency thereof. 


\section{DISCLAIMER}

Portions of this document may be illegible in electronic image products. Images are produced from the best available original document. 


\section{MASTER}

AQUEOUS FOAM SURFACTANTS FOR GEOTHERMAL DRILLING FLUIDS:

I. SCREENING *

P. B. Rand

O. J. Montoya

Sandia Laboratories, Albuquerque, New Mexico 87185**

\section{ABSTRACT}

Aqueous foam is a promising drilling fluid for geothermal wells because it will minimize damage to the producing formation and would eliminate the erosion problems of air drilling. Successful use of aqueous foam will require a high foaming surfactant which will: 1. be chemically stable in the harsh thermal and chemical environment, and 2. form stable foams at high temperatures and pressures. This paper presents the procedures developed to generate and test aqueous foams and the effects of a $260^{\circ} \mathrm{C}$ temperature cycle on aqueous surfactant solutions. More than fifty selected surfactants were evaluated with representatives from the amphoteric, anionic, cationic, and nonionic classes included. Most surfactants were severely degraded by this temperature cycle; however, some showed excellent retention of their properties. The most promising surfactant types were the alkyl and alkyl aryl sulfonates and the ethoxylated nonionics.

This work was supported by the U. S. Department of Energy, (DOE) under contract DE-AC04-76 DP00789.

${ }^{\star \star}$ A U. S. DOE facility.

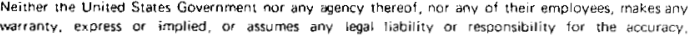
completeness, or useituness of any information. apparatus, product, or prucess disclosed, or

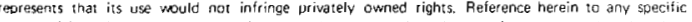
commercial produci, process, or service by irade narne, trademark. manutacturer, or otherwise, does

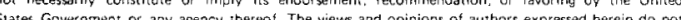

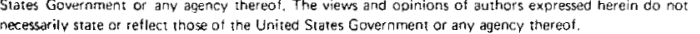




\section{Table of Contents}

Abstract

Introduction

Experimental

surfactants

11

Results and Discussion

Conclusions 


\section{Iist of Illustrations}

Figures

Page

1. Aqueous Foam Generator

26

2. Experimental Setup for Foam Drainage Test

27

Tables

I. Effect of $260^{\circ} \mathrm{C}$ on Amphoteric Surfactant Solutions 20

II. Effect of $260^{\circ} \mathrm{C}$ on Anionic Surfactant solutions 21

III. Effect of $260^{\circ} \mathrm{C}$ on Cationic and Proprietary Surfactant Solutions

IV. Effect of $260^{\circ} \mathrm{C}$ on Nonionic surfactant solutions 23

V. Surfactants Selected for Further Evaluation 24

Appendix A 

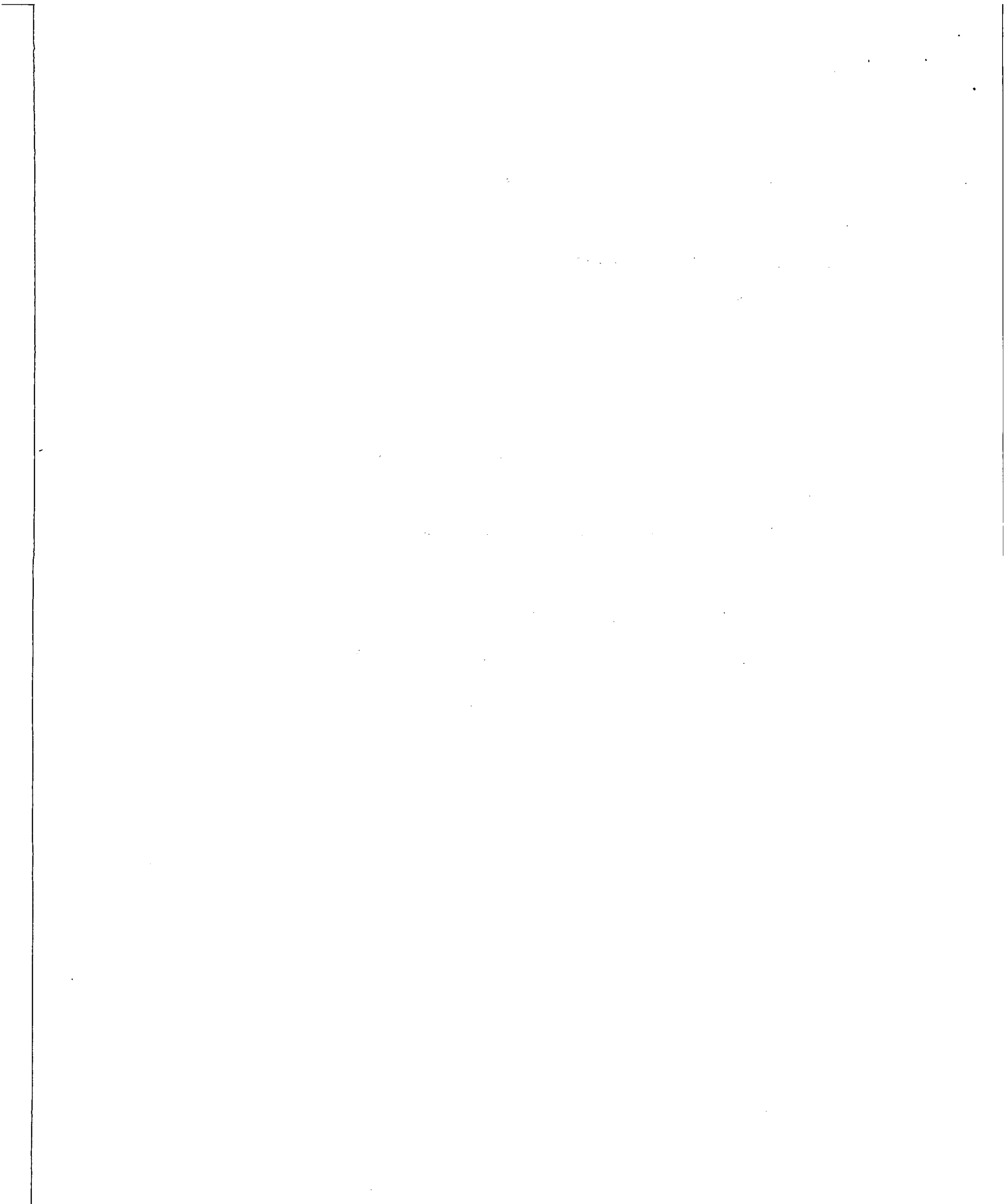
INTRODUCTION

- Deep well rotary drilling requires the use of a drilling fluid which has many functions including; removal of solids, cooling, lubrication, and pressure control.1,2 water based muds, made with Betonite or native clays, are the most commonly used drilling fluids. Many other fluids including oil based muds, aqueous foams, and air or other gases are also used. ${ }^{3}$ Aqueous foams have been used as a fluid in wells for workovers and drilling operations around the world. 4-7 Some work has also been done to determine the properties of aqueous foams for drilling fluid applications. ${ }^{8-11}$ These references illustrate that aqueous foam is a useful drilling fluid noted for its excellent lifting ability, high penetration rates, and low annular velocities.

Drilling geothermal wells presents some unique problems as evidenced by the fact that geothermal well drilling costs are two to four times the cost of oil or gas wells. Aqueous foams have been identified as a promising drilling fluid in the under-pressured formations frequently found in geothermal reservoirs. 12 The advantages of foam for geothermal drilling are: 1. it will not harm the producing formations, and 2. the low annular velocities will greatly reduce the erosion of the drill string caused by air drilling. Successful use of foam will require a foaming agent system that will not degrade rapidly in the harsh thermal and chemical environment and that will form stable foams in a high temperature and 
pressure environment. Some work has been done with aqueous foams at high temperatures for cleanout and stimulation in oil wells 4 and for geothermal drilling. 13

Because of its low density, successful use of foam will require a high pressure rotary drilling head suitable for geothermal well use. This will allow balanced drilling thus allowing control of formation water and steam. Corrosion problems may require the use of nitrogen rather than air to make the foam. If corrosion inhibitors can be found that will work in the high temperature geothermal environment, this may not be necessary.

The first step in developing foam drilling fluids for geothermal use is to find chemically stable foaming agents or surfactants to make the foam. This paper will present the results of a study to determine the thermal stability of a wide variety of commercially available surfactants in aqueous solution. Tests were run on the solution and foams made with the solution before and after exposure to $260^{\circ} \mathrm{C}$ for two hours. These tests have shown that several types of commercially available surfactants may be suitable foaming agents for geothermal drilling. 


\section{EXPERIMENTAL}

- Surfactant solutions were exposed to a $260^{\circ} \mathrm{C}\left(500^{\circ} \mathrm{F}\right)$ aging cycle in heavy wall corrosion resistant stainless steel tubing with "SWAGELOK" end caps. The solutions were prepared by mixing fifty weight percent of the surfactant as received in deionized water. A few surfactants were aged as 1.0 and 0.2 weight percent solutions in a Baroid $500 \mathrm{cc}$ high temperature aging cell due to limited solubility. This is noted where applicable in the data. The aging cycle consisted of the following: a. ambient to $260^{\circ} \mathrm{C}$-two hours b. $260^{\circ} \mathrm{C}$-two hours and c. $260^{\circ} \mathrm{C}$ to ambient-three hours. All containers were cleaned and run through the $260^{\circ} \mathrm{C}$ temperature cycle between uses to minimize contamination from previous samples.

Aqueous foams for evaluation were made by metering nitrogen gas and surfactant solution into a static mixer as illustrated in Figure 1. Commercially available static mixers, such as "Kenics," work well however a tube filled with coarse stainless steel wool provided more uniform foams over a broader flow range than the commercial mixers. This technique of foam generation gave uniform small celled foams with controlled density for evaluation. The density of all foams was controlled to $45.0 \pm 5.0 \mathrm{Kg} / \mathrm{m}^{3}$ except as noted.

Foams were made with the surfactant solutions before and after exposure to the $260^{\circ} \mathrm{C}$ temperature cycle. Density and time to fifty percent by weight drainage were determined on each foam sample. The values reported are the average of 
three determinations. Drainage time was measured using the setup shown in Figure 2. The foams were also evaluated qualitatively by observing their cell structure. Ratings of good, fair, and poor were assigned on the basis of the uniformity of their cell structure. Solution $\mathrm{F} H$ was also measured before and after exposure using a Beckman model 4500 digital $\mathrm{pH}$ meter. The $\mathrm{pH}$ values reported are the average of two determinations. 


\section{SURFACTANTS}

- A wide variety of high foaming surfactants were selected for evaluation on the basis of their chemical structure and/or supplier's recommendations. Amphoteric, anionic, cationic, and nonionic types with varying chemical structure were evaluated. The books by Schwartz and Perry 13,14 and McCutcheons ${ }^{15}$ were used extensively to determine chemical structure and availability respectively.

Amphoteric surfactants evaluated were the betaines, amido betaines, sulfo amido betaines, an imidazolene compound, and a proprietary fluoro-chemical material. Most anionic surfactants evaluated were sulfonic acid salts or sulfonates. Alkyl, alkyl aryl, and perfluoro alkyl sulfonates were included. Other anionic types tested were an ethoxylated alkyl sulfate and an amide linked carboxylic acid salt. Cationic types evaluated were an imidazolene compound, ethoxylated tertiary amines, and a proprietary fluorochemical material. The nonionic surfactants tested were ethoxylated fatty alcohols, ethoxylated alkyl aryl alcohols, and a polyoxypropylene - polyoxyethylene block copolymer. 


\section{RESULTS AND DISCUSSION}

- The effects of a $260^{\circ} \mathrm{C}$ temperature cycle on amphoteric, anionic, cationic and proprietary, and nonionic surfactants are presented in Tables I-IV. The surfactants are identified by chemical type and reference number. The trade names and suppliers are given in Appendix A. The original properties or properties before exposure given are density, drainage time, cell structure rating, and solution $\mathrm{pH}$. The effects of the temperature cycle are shown in the last three columns listing; change in drainage, change in $\mathrm{pH}$, and cell structure rating.

The density range of $45.0 \pm 5.0 \mathrm{~kg} / \mathrm{m}^{3}$ was chosen as representative of the preformed stable foams used as drilling fluids. This density is equivalent to a liquid volume fraction of 0.045 or a weight of $0.37 \mathrm{lbs} / \mathrm{gal}$. A few of the poorer foaming surfactants would not make foams of $45.0 \pm 5 \mathrm{~kg} / \mathrm{m}^{3}$ in our generator. This is noted in the original cell structure column.

Foam drainage is defined as the time to fifty percent weight loss of a preformed foam. It is a measure of density stability of the foam. Foams with long drainage times or good density stability are desirable for drilling fluid applications. The drainage data are presented as the time in minutes to 50 percent by weight drainage and the percentage difference in drainage time between the original and exposed sample. 
All foams tested were qualitatively evaluated for cell structure and given ratings of good--small uniform cells, fairnonuniform cell structure and poor-nonuniform cells with large voids. This test is important because it indicates that degradation products from the surfactant are acting as antifoamers or defoamers in the solution. This implies that higher temperatures or longer times would give solutions incapable of making foams. This would be disasterous for foam drilling fluid applications. Some foams made with surfactants exposed to $260^{\circ} \mathrm{C}$ retained or even improved their drainage time; however, they would not make fine-uniform celled foams indicating the importance of this rating. Many surfactant solutions would not make foams after exposure to $260^{\circ} \mathrm{C}$. This is noted with a "no foam" rating in the aged cell structure column.

The change in $\mathrm{pH}$ can only be treated as a relative value indicative of surfactant degradation. The mechanisms of the surfactant degradation would have to be understood before any additional meaning can be obtained from these data.

The data are presented somewhat arbitrarily in the order of decreasing stability as indicated by the change in drainage after exposure to $260^{\circ} \mathrm{C}$. Although drainage is important, the true value of a surfactant for geothermal foam drilling must also consider the change in foam cell structure, solution $\mathrm{pH}$ and other factors yet to be evaluated. This ordering system does tend to put the best surfactants at the top of the list in each class. All data presented are the average of 
three determinations.

The aging data presented in Table I on amphoteric surfactants shows that these materials, as a class, performed poorly. Only one, a coco betaine, had good cell structure after aging accompanied by a 28.0 percent decrease in drainage time. A cetyl betaine gave a small decrease in drainage time; however, the poor foam cell structure after aging indicates problems will arise after longer exposure times. Most of the amphoteric surfactants produced no foam at all after exposure to $260^{\circ} \mathrm{C}$. It is interesting to note that one of the surfactants giving no foam is another coco betaine, indicating that there are differences between surfactants sold as the same chemical type from different manufacturers. One surprise in these data was the failure of a fluorochemical surfactant, normally noted for its chemical stability.

The anionic surfactants showed less degradation as a class as shown in Table II. Most anionic surfactants evaluated made foam after our $260^{\circ} \mathrm{C}$ cycle. The best anionic surfactants evaluated were a sodium alkyl aryl polyether sulfonate and a sodium alkyl amide sulfonate which both show small changes in drainage time, good cell structure after exposure, and small changes in pH. The first surfactant listed, a sodium alkyl ester sulfonate, showed a large increase in drainage time. In this case, hydrolytic cleavage of the ester linkage will generate a fatty alcohol which is an excellent foam stabilizer which probably explains this surprising result. Although promising, this result must be viewed with caution as the foam cell structure was 
rated only fair after exposure to $260^{\circ} \mathrm{C}$. Other anionic surfactants which will be evaluated in future tests are the alpha olefin sulfonate and the triethanol amine alkyl aryl sulfonate. Because of the known hydrolytic instability of the sulfuric esters (sulfates), very few were evaluated. Data on an ethoxylated ammonium alkyl sulfate and an alkyl sulfate are included.

The data on cationic and proprietary surfactants are given in Table III. The cationic surfactants, as a class, performed poorly. One, an ethoxylated amine, had an increase in drainage time; however, it had poor cell structure after aging. Several propriatary foaming agents, recommended for foam drilling, were evaluated. One system, which is recommended for use as a foaming agent with steam in oil well stimulation procedures, performed well. This system gave a moderate decrease in drainage, good cell structure, and a small change in solution $\mathrm{pH}$ after aging.

The nonionic surfactants, as a class, performed well as shown in Table IV. After exposure to $260^{\circ} \mathrm{C}$, two showed an increase in drainage time and made foams with good cell structures. One, an ethoxylated fatty alcohol, gave very little shift in solution $\mathrm{pH}$.

Surfactants selected for further evaluation are listed in Table $V$ with selected data. Selection was based first on their performance in these screening tests but also on their chemical structures. This study is the first step in finding 
useful surfactants for geothermal foam drilling fluids. The promising surfactants will now be exposed to acidic, basic and simulated geothermal brine solutions at $260^{\circ} \mathrm{C}$ and higher temperatures. These tests will establish the chemical stability of surfactant solutions in various chemical environments. The final step to establish surfactant usefullness will be to make and evaluate aqueous foams at high temperatures and pressures in an autoclave. Successful surfactants from these tests will then be formulated with additives such as corrosion inhibitors, scale inhibitors, antioxidants, and caustic chemicals to make foaming agent systems for geothermal drilling. 


\section{CONCLUSIONS}

- Techniques have been developed to expose aqueous surfactant solutions to a high temperature cycle, to generate foams with controlled density, and to evaluate the foams made. These techniques were used to evaluate more than fifty surfactants to establish their resistance to a $260^{\circ} \mathrm{C}$ temperature cycle as a first step in finding surfactants for use as foaming agents for geothermal drilling. Most surfactants evaluated were severely degraded by the $260^{\circ} \mathrm{C}$ temperature; however, about one in five showed good resistance. These promising surfactants will be tested after exposure to various chemical environments at $260^{\circ} \mathrm{C}$ and higher temperatures and pressures in a continuing program to find foaming agents for geothermal drilling. 


\section{REFERENCES}

1. A Primer of Oilwell Drilling, Petroleum Extension Service, University of Texas at Austin, July, 1975.

-2. Principles of Drilling Fluid Control Petroleum Extension Service, University Extension Service, University of Texas at Austin, July, 1974 .

3. "What to Consider When Selecting Drilling Fluids," S. 0 . Hutchison, G. W. Anderson, World Oil, October, 1974.

4. "Foam Workovers Cut Costs 50\%," S. O. Hutchison, World Oil, November, 1969.

5. "Near Gauge Holes Through Permafrost," G. W. Anderson, Oil and Gas Journal, September 20, 1971.

6. "West Texas Workovers with Foam Gain Favor," W. B. Bleakly, Oil and Gas Journal, March 12, 1973.

7. "Foam Aids Drilling in Iran's Zargras Mountain Area," o. Garinini et al., Oil and Gas Journal, August 16, 1971.

8. "Flow Behavior of Foam as a Well Circulative Fluid," A. H. Beyer et al., Society of Petroleum Engineer, Paper No. SPE- 3986, 1972 .

9. "Factors Affecting Foam Circulation in Oil Wells," R. S. Millhone et al., Society of Petroleum Engineers, Paper No. SPE-4001, 1972 .

10. "Flow Regimes of Stable Foams," M. S. Hoffer et al., Industrial Engineering Chemistry, V8, No. 3, P. 483-490, August, 1969.

11. "Test Data Till Theory Gap on Using Foam as a Drilling Fluid," B. J. Mitchell, Oil and Gas Journal, September 6, 1971.

12. "Development of Drilling Foams for Geothermal Applications," W. J. McDonald, L. J. Remont, W. A. Rehm, M. E. Chenevert, 
Maurer Engineering Report No. TR-79-7, January, 1979.

13. Surface Active Agents - Their Chemistry and Technology,

A. M. Schwartz and J. W. Perry; R. E. Krieglr Publishing Co., 1978 .

14. Surface Active Agents and Detergents - Volume II, A. M. Schwartz, J. W. Perry, and J. Berch; R. E. Krieger Publishing Co., 1977.

15. McCutcheons Detergents and Emulsifiers, 1978 Annual, MC Publishing Co., 1978. 
TABIE I

EFFECT OF $260^{\circ} \mathrm{C}$ ON AMPHOTERIC SURFACTANT SOLUTIONS

\section{CHEMICAL TYPE}

CETYL BETAINE

COCO BETAINE

COCO AMIDO BETAINE

COCO BETAINE

COCO IMIDAZOLINE BETAINE

COCO AMIDO BETAINE

COCO BETAINE

COCO BETAINE

COCO AMIDO BETAINE

SULFO COCO AMIDO BETAINE

SULFO COCO AMIDE BETAINE

COCO AMINO ACID, K SALT

COCO IMIDAZOLINIUM DERIVATIVE

COCO IMIDAZOLINE BETAINE

PROPRIETARY FLUOROCHEMICAL
ORIGINAL PROPERTIES

\begin{tabular}{|c|c|c|c|}
\hline \multirow[b]{2}{*}{$\begin{array}{l}\text { REF . } \\
\text { NO. (1) }\end{array}$} & \\
\hline & $\begin{array}{l}\text { DENSITY } \\
\left(\mathrm{KG} / \mathrm{M}^{3}\right) \\
\end{array}$ & $\begin{array}{l}\text { DRAINAGE } \\
\text { TIME/MIN. }\end{array}$ & $\begin{array}{c}\text { CELL } \\
\text { STRUCTURE }\end{array}$ \\
\hline 1 & 46.4 & 5.63 & GOOD \\
\hline 2 & 45.6 & 6.83 & GOOD \\
\hline 3 & 47.0 & 5.66 & GOOD \\
\hline 4 & 47.6 & 5.22 & GOOD \\
\hline 5 & 45.8 & 6.32 & GOOD \\
\hline 6 & 46.2 & 5.29 & GOOD \\
\hline 7 & 48.5 & 4.96 & GOOD \\
\hline 8 & 44.6 & 6.79 & GOOD \\
\hline 9 & 48.7 & 5.03 & GOOD \\
\hline 10 & 45.3 & 5.33 & GOOD \\
\hline 11 & 48.2 & 6.44 & GOOD \\
\hline 12 & 44.5 & 4.85 & GOOD \\
\hline 13 & 46.8 & 6.35 & GOOD \\
\hline 14 & 45.7 & 6.82 & GOOD \\
\hline 15 & 44.4 & 9.83 & GOOD \\
\hline
\end{tabular}

EFFECT OF $260^{\circ} \mathrm{C}$ CHANGE IN CHANGE DRATN. 8 IN $\mathrm{PH}$

$-4.08$

-28.3
-38.5

$-39.6$

$-49.8$

$-50.5$

NO DATA

NO FOAM

NO FOAM

NO FOAM

NO FOAM

NO FOAM

NO FOAM

NO FOAM

NO FOAM
$+1.45$

+1.45
+1.82
+1.60

$+1.82$

$+1.60$

-0.36
-4.53

$+1.97$

$+0.62$

$+1.83$

$+1.77$

$+0.67$

$-0.03$

$-1.84$

$-1.34$

$-1.72$

$-1.27$
CELI

STRUCTURE

\section{POOR}

GOOD

POOR

POOR

GOOD

POOR

POOR

NO FOAM

NO FOAM

NO FOAM

NO FOAM

NO FOAM

NO FOAM

NO FOAM

NO FOAM 
TABLE II

EFFECT OF $260^{\circ} \mathrm{C}$ ON ANIONIC SURFACTANT SOLUTIONS

\section{CHEMICAL TYPE}

SODIUM ALKYL ESTER SULFONATE POTASSIUM PERFLUORO ALKYL SULFONATE SODIUM ALKYL AMIDE SULFONATE SODIUM ALKYL ARYL POLYETHER SULFONATE SODIUM ALPHA OLFFIN SULFONATE

SODIUM ALKYL AMIDE SULFONATE

SODIUM ALPHA OLEFIN SULFONATE

SODIUM ALKYL AMIDE CARBOXYLIC ACID

TEA ALKYL ARYL SULFONATE

SODIUM ALKYL SULFONATE

SODIUM ALPHA OLEFIN SULFONATE

SODIUM ALPHA OLEFIN SULFONATE

ETHOXYLATED AMMONIUM ALKYL SULFATE

SODIUM ALKYL SULFONATE

POTASSIUM PERFLUORO ALKYL SULFONATE (2)

PROPRIETARY ANIONIC

PROPRIETARY ANIONIC

SODIUM ALKYL SULFATE
ORIGINAL PROPERTIES

REF . DENSITY DRAINAGE CELT

NO. (1) $\left(\mathrm{KG} / \mathrm{M}^{3}\right) \quad$ TIME/MIN.

STRUCTURE

41.4

92.8

48.9

46.1

43.8

43.1

48.

46.4

45.1
79.1

44.7

44.

44.8

44.0

44.5

44.8

89.6

45.6

42.5

43.5

\subsection{8}

2.58

4.05

5.12

7.84

4.97

7.82

5.86

8.74
4.27

5.62

8.38

9.04

5.88

5.01

2.78

7.64

6.62

8.53 GOO DENSITY

GOOD

GOOD

GOOD

GOOD

GOOD

GOOD

HIGH DENSITY

GOOD

GOD

GOD

GOOD

GOOD

HIGH DENSITY

GOOD

GOOD

GOOD
EFFECT OF $260^{\circ} \mathrm{C}$

CHANGE IN CHANGE

DRAIN. \& IN pH

CELI STRUCTURE

$6.50+232$.

5.30+49.2

$5.02-5.18$

39

8.39

7.37
8.30

-3.51
-5.86

$-8.60$

$-12.0$

$-19.4$

$-20.4$

$-21.0$

$-25.0$

$-45.9$

$-54.5$

54.5

7.32 NO DATA

$-2.65$

$-0.76$

$-0.81$

$+0.78$

$-2.73$

$-0.32$

$-0.59$

$-1.41$

$-0.28$

$+1.14$

$-1.21$

$-2.31$

$-1.86$

$-3.88$

$+1.04$

NO FOAM -4.54

$-3.46$

$-4.40$

6.79 NO FOAM

6.49 NO FOAM

$-6.80$
FAIR

FAIR

FAIR

GOOD

GOOD

GOOD

GOOD

GOOD

FAIR

GOOD

POOR

POOR

POOR

GOOD

POOR

POOR

NO FOAM

NO FOAM

NO FOAM

NO FOAM

(1) See Appendix A for trade names and suppliers.

(2) Aged and tested as $0.2 \% / w t$ solution. 
TABLE III

EFFECT OF $260^{\circ} \mathrm{C}$ ON CATIONIC AND PROPRIETARY SURFACTANT SOLUTIONS

CHEMICAL TYPE

\section{CATIONIC}

ETHOXYLATED AMIN

ETHOXYLATED AMINE

PROPRTETARY FLUOROCHEMTCAI 36

ALKYL HYDROXYETHYL IMIDAZOLINE 38

DENSITY DRAINAGE

$\left(\mathrm{KG} / \mathrm{M}^{3}\right)$ TIME/MIN.

CELL

STRUCTURE

\begin{tabular}{|c|c|c|c|c|c|}
\hline $\begin{array}{c}43.1 \\
150 . \\
46.7 \\
54.7\end{array}$ & $\begin{array}{l}3.17 \\
7.20 \\
8.06 \\
4.73\end{array}$ & HIGH & $\begin{array}{l}\text { GOOD } \\
\text { DENSITY } \\
\text { GOOD } \\
\text { DENSITY }\end{array}$ & $\begin{array}{r}9.44 \\
9.53 \\
6.09 \\
10.81\end{array}$ & $\begin{array}{l}+23.0 \\
\text { No FOAM } \\
\text { NO FOAM } \\
\text { NO FOAM }\end{array}$ \\
\hline
\end{tabular}

ANGE IN

DRAIN. \&

\section{PROPRIETARY}

\section{NOT GIVEN}

NOT GIVEN

NOT GIVEN

39

40
41

43.8

50.8

8.63
6.28

6.28
6.92

HIGH DENSITY

10.81

NO FOAM

\section{GOOD}

GOOD
9.51
6.92
$-17.0$
$-47.4$
$-50.0$

OF $260^{\circ}$

CHANGE

IN $\mathrm{pH}$

CELI STRUCTURE

\section{-0.96 POOR \\ -1.37 NO FOAM \\ -2.07 NO FOAM}

NO DATA NO FOAM

\section{$+0.23 \quad$ GOOD}

+1.35 POOR

POOR

(1) See Appendix A for trade names and suppliers. 
TABLE IV

EFFECT OF $260^{\circ} \mathrm{C}$ ON NONIONIC SURFACTANT SOLUTIONS

\section{CHEMICAL TYPE}

ETHOXYLATED FATTY ALCOHOL

ETHOXYLATED ALKYL ARYL ALCOHOL

ETHOXYLATED LAURYL ALCOHOL (POE $=12$ )

ETHOXYLATED TRIDECYL ALCOHOL

ETHOXYLATED NONYL PHENOL

ETHOXYLATED LAURYL ALCOHOL (POE = 23)

ETHOXYLATED OCTYL PHENOL (POE $=40)$

ETHOXYLATED OCTYL PHENOL $($ POE $=70)$

POLYOXYETHYIENE POLYOXYRROPYLENE BLOCK COPOLYMER

PROPRIETARY NONIONIC
ORIGINAL PROPERTIES

DENSITY DRAINAGE CELL

$\left(\mathrm{KG} / \mathrm{M}^{3}\right)$ TIME/MIN.

NO. $(1$

42

43

44

45

46
44.7

47.2
48.7

44.2

47.0

49.2

44.9

46.3

57.4

44.6
3.42

3.42
3.87

3.10

3.12

3.20

3.33

3.42

3.68

4.94

4.94
9.46
STRUCTURE

\section{GOOD}

GOOD

GOOD

GOOD

FAIR

GOOD

FAIR

POOR

HIGH DENSITY

GOOD
EFFECT OF $260^{\circ} \mathrm{C}$ CHANGE IN CHANGE DRAIN. \&

ph

\subsection{5}

6.33

5.55

5.85

5.31

6.43

6.27

6.16

$+20.2$

$+11.6$

$-2.9$

$-5.4$

$-5.9$

$-8.7$

$-11.1$

$-11.4$

$7.08-16.4$

6.72 NO FOAM
IN $\mathrm{pH}$

$-0.02$

$-1.70$

$-0.56$

$-1.86$

$-0.02$

$-0.99$

$-0.11$

$-0.22$

$-2.65$

INSOLUBLE
CELL

STRUCTURE

GOOD

GOOD

FAIR

GOOD

FAIR

GOOD

FAIR

POOR

FAIR

(1) See Appendix A for trade names and suppliers. 
TABLE V

SURFACTANTS SELECTED FOR FURTHER EVALUATION

\section{CHEMICAL TYPE}

COCO BETAINE

SODIUM ALKYL ESTER SULFONATE

POTASSIUM PERFLUORO ALKYL SULFONATE

SODIUM ALKYL ARYL POLYETHER SULFONATE

SODIUM ALPHA OLEFIN SULFONATE

SODIUM ALKYL AMIDE SULFONATE

SODIUM ALPHA OLEFIN SULFONATE

TRIETHANOL AMINE ALKYL ARYL SULFONATE

ETHOXYLATED TERTIARY AMINE

PROPRIETARY

ETHOXYLATED FATTY ALCOHOL

ETHOXYLATED ALKYL ARYL ALCOHOI

ETHOXYLATED LAURYL ALCOHOL

\begin{tabular}{r} 
REFER \\
NUMB \\
\hline \\
2 \\
2 \\
16 \\
17 \\
19 \\
20 \\
21 \\
22 \\
24 \\
35 \\
39 \\
42 \\
43 \\
47
\end{tabular}

CHANGE IN
DRAINAGE $\%$

$-28.3$

+232 .

$+49.2$

-3.51
-5.86

$-8.60$

$-12.0$

$-20.4$

$+23.0$

$-17.0$

$+20.2$

+11.6
-8.70
CELL STRUCTURF

AFTER AGING

GOOD

FAIR

FAIR

GOOD

GOOD

GOOD

GOOD

GOOD

POOR

GOOD

GOOD

GOOD

GOOD
CHANGE IN $\mathrm{pH}$

$+1.82$

$-2.65$

$-0.76$

$+0.78$

$-2.73$

$-0.32$

$-0.59$

$-0.59$

$-0.28$

$-0.96$

$+0.23$

$-0.02$

$-1.70$

$-0.99$ 
APPENDIX A

SURFACTANTS EVALUATED

REFERENCE

\section{CHEMICAL TYPE}

\section{CETYL BETAINE}

COCO AMIDO BETAINE

COCO BETAINE

COCO IMIDAZOLENE BETAINE

COCO AMIDO BETAINE

COCO BETAINE

COCO BETAIN

COCO AMIDO BETAINE

SULFO COCO AMIDO BETAINE

SULFO COCO AMIDO BETAINE

COCO AMINO ACID, K SALT

COCO IMIDAZOLINIUM DERIVATIVE

COCO IMIDAZOLINE BETAINE

PROPRIETARY FLUOROCHEMICAL

SODIUM ALKYL ESTER SULFONATE

PERFLUORO ALKYL SULFONATE, K SALT

SODIUI ALKYL AMIDE SULFONATE

SODIUM ALKYL ARYL POLYETHER SULFONATE

SODIUM ALPHA OLEFIN SULFONATE

SODIUM ALKYL AMIDE SULFONATE

SODIUM ALPHA OLEFIN SULFONATE

SODIUM ALKYL AMIDF CARBOXYLEC ACID

TEA ALKYL ARYL SULFONATE

SODIUM ALKYL ARYL SULFONATE

SODIUM ALKYL SULFONATE

SODIUM ALPHA OLEFIN SULFONATE

SODIUM ALPHA OLEFIN SULFONATE

ETHOXYLATED AMMONIUM ALKYL SULFATE

SODIUM ALKYL SULFONATE

POTASSIUM PERFLUORO ALKYL SULFONATE

PROPRIETARY ANIONIC

PROPRIETARY ANIONIC

SODIUM ALKYL SULFATE

ETHOXYLATED AMINE

PROPRILTARY FLUOROCHEMICAL

ALKYL HYDROXYETHYL IMIDAZOLINE

PROPRIETARY

PROPRIETARY

PROPRIETARY

ETHOXYLATED FATTY ALCOHOL

ETHOXYLATED ALKYL ARYL ALCOHOL

ETHOXYLATED LAURYL ALCOHOL

ETHOXYLATED TRIDECYL ALCOHOL

ETHOXYLATED NONYL PHENOL

ETHOXYLATED LAURYL ALCOHOL

ETHOXYLATED OCTYL PHENOL

ETHOXYLATED OCTYL PHENOL

POE-POP BLOCK COPOLYMER

PROPRIETARY NONIONIC
TRADENAME

PRODUCT BCO

VELVETEX BC

VELVETEX BAW

VELVETEX BCW

CARSONAM C

CARSONAM 3

VARION CDG

SCHERCOTAIN CAB

SCHERCOTAIN CAB

VARION CAS

MAFO $\mathrm{C}-12$

SCHERCOTERIC MS-2

CARSONAM C-SF

ZONYL FSB

LANTHANOL LAI

FLUORAD FC-95

IGEPON TM-4

TRITON $\mathrm{X}-200$

SULFRAMIN 14/16 AOS

IGEPON TC-42

LAKEWAY 301-10

SARCOSYL NL-30

NINEX N-300

BIOSOFT D35X

ALKANOL $189 \mathrm{~s}$

BIOTERGE AS-40

LAKEWAY 301-10-UB

ALIPAL CS-128

PETRONET $R$

FLUORAD FC-98

RICHONOL $\mathrm{X}-7079$

RICHONOL 7103

DUPONOL ME

VARONIC K215 LC

VARONIC T205 LC

ZONYL FSC

VARINE $C$

THERMOPHOAM BW-D

THERMOPHOAM A

AMPLI-FOAM

WITCONOL SN-90

WITCONOL NP-120

TRICOL LAL-12

TRICOL TDA-II

TRITON $\mathrm{N}-401$

TRICOL LAL-23

TRITON $X-405$

TRITON $x-705$

PLURONIC F-87

TRITON BG-10
SUPPLIER

UPONT DE NEMOURS \& CO.

TEXTILANA CORP.

TEXTILANA CORP.

TEXTILANA CORP.

CARSON CHEMICALS INC.

CARSON CHEMICALS INC.

WITCO CHEMICAL CORP.

ASHLAND CHEMICAL CO.

SCHER CHEMICALS

SCHER CHEMICALS

ASHLAND CHEMICAL CO.

MAZER CHEMICALS INC.

SCHER CHEMICALS

CARSON CHEMICALS INC.

DUPONT DE NEMOURS \& $\mathrm{CO}$

STEPHAN CHEMTCAL CO.

3M CO.

GAF CORP.

ROHM \& HAAS CO.

WITCO CHEMICAL CORP.

GAF CORP.

LAREWAY CHEMICALS INC.

CIBA-GIGY CORP.

STEPHAN CHEMICAL CO.

STEPHAN CHEMICAL CO

DUPONT DE NEMOURS \& $\mathrm{CO}$

STEPHAN CHEMICAL CO.

LAKEWAY CHEMICALS INC.

GAF CORP.

DUPONT DE NEMOURS \& CO $3 \mathrm{M} \mathrm{CO}$.

THE RICHARDSON CO.

THE RICHARDSON CO.

DUPONT DE NEMOURS \& CO.

ASHLAND CHEMICAL CO.

ASHLAND CHEMICAL CO.

DUPONT DE NEMOURS \& $\mathrm{CO}$

ASHLAND CHEMICAL CO.

FARBEST CORP

FARBEST CORP.

MILCHEM INC.

WITCO CHEMICAL CO.

WITCO CHEMICAL CO.

EMERY INDUSTRIES

EMERY INDUSTRIES

ROHM AND HAAS CO.

EMERY IN

ROHM \& HAAS CO.

ROHM \& HAAS CO.

BASE WYANDOITE

ROHM \& HAAS CO. 


\section{AQUEOUS FOAM GENERATOR}

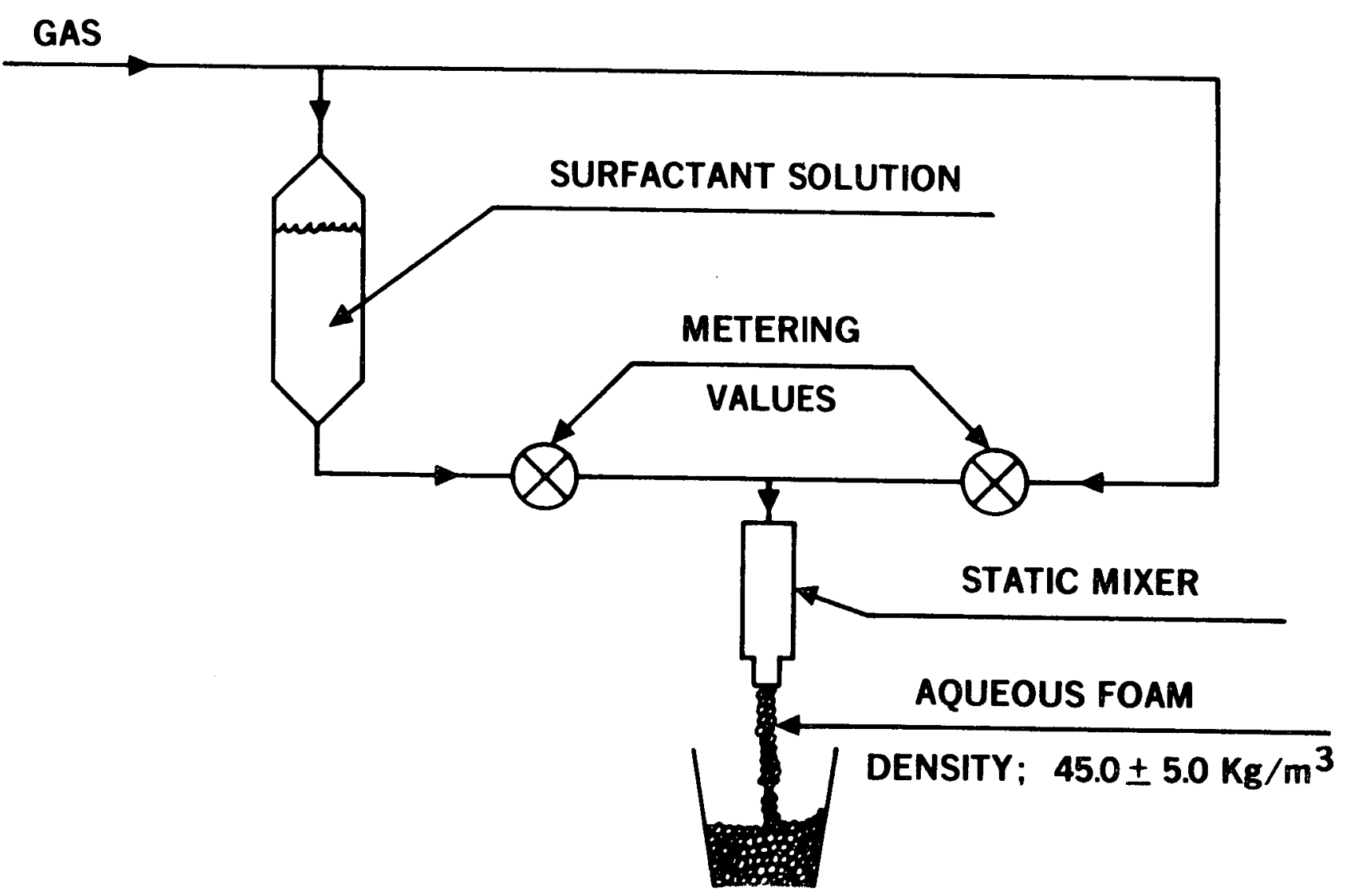

FIGURE 1 


\section{FOAM DRAINAGE TEST}

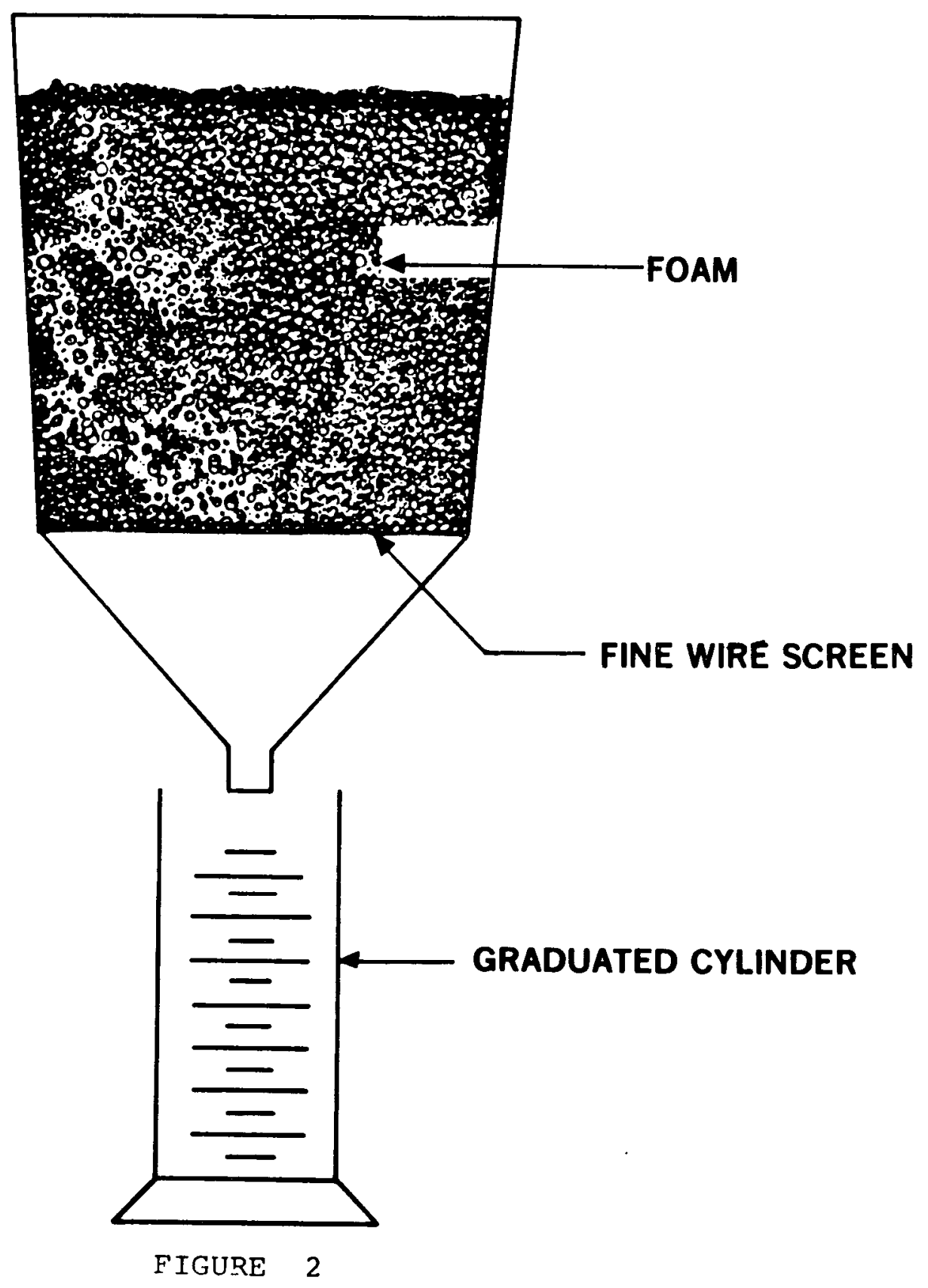




\section{DISTRIBUTION}

American coldset Corporation

(2)

P. O. Box 615

Addison, Texas 75001

Attention: J. R. Wingerter

Mark C. Thompson

Amoco Production Research

Research Center

P. O. Box 591

Tulsa, Oklahoma 74102

Attention: L. B. Wilder

Keith Millheim

Atlantic Richfield

$R \& D$ Department

P. O. Box 2819

Dallas, Texas 75221

Attention: Thomas K. Perkins

John H. Striegler

A. T. Havlik Associates

5540 Pine Cone Road

La Crescenta, California 91214

Big Chief Drilling Company

P. O. Box 14837

Oklahoma City, oklahoma 73113

Attention: William A. Glass

Brigham Young University

Provo, Utah 84602

Attention: K. W. Chase

Mechanical Engineering

Department, $242 \mathrm{CB}$

Battelle-Columbus Laboratory

505 King Avenue

Columbus, Ohio 43201

Attention: Ellis L. Foster, Manager

Defense/Space Systems

Material Requirements Program

Director

Baroid

6400 Uptown Boulevard, $365 \mathrm{~W}$

Albuquerque, New Mexico 87110

Attention: Gene Polk 
Baker Tool

P. O. Box 40129

Houston, Texas 77040

Attention: W. O. Berryman

Baroid

P. O. Box 1675

Houston, Texas 77001

Attention: W. M. Carnicom

Brinado Co.

6003 Murphy Ave.

Houston, Texas 77033

Attention: M. R. Childers

Continental oil Company

Production Research Division

Ponca City, Oklahoma 74601

Attention: Elard L. Haden

Cities Service Company

P. O. Box 300

Tulsa, Oklahoma 74102

Attention: B. F. Caver

Chevron oil Field Research

P. O. Box 446

La Habra, California 90631

Attention: A. Rosman

Christensen Diamond Products, Inc.

2532 South 3270 west Street

Salt Lake City, Utah 84119

Attention: Bruce H. Walker

Howard Link

Coy Fielder

David Rowley

Completion Technology Company

(2)

4200 Westheimer Road

Suite 211

Houston, Texas 77027

Attention: Robert Jorda

George Suman

Comision Federal de Electricidad

P. O. Box 248

Calexico, California 92231

Attention: $B$. Dominguez 
Commission of the European Communities

Rue de la Loi 200

B-1040 Brussels

Belgium

Attention: Pierre Ungemach, Project Manager

Geothermal Energy R\&D

Chevron Oil Field Research Co.

P. O. Box 446

La Habra, California 90631

Attention: R. S. Millhone

Chevron USA, inc.

P. O. Box 5355

Bakersfield, California 93109

Attention: G. W. Anderson

S. O. Hutchison

Department of Energy (3)

Bartlesville Energy Technology Center

P. O. Box 1398

Bartlesville, Oklahoma 74003

Attention: C. RaY Williams

R. M. Ray

W. Drake

Department of Energy (4)

Morgantown Energy Technology Center

P. O. Box 880

Morgantown, West Virginia 26505

Attention: B. Wise

L. Schrider

A. A. Pitrolo

L. Strickland

Department of Energy (3)

Albuquerque Area office

Albuquerque, New Mexico

87115

Attention: DOE/ALO SPD

Department of Energy

Division of Product and Materials

Management

Grand Junction Office

P. O. Box 2567

Grand Junction, Colorado 81501

Attention: Philip Dodd 
Department of Energy

Division of Geothermal Energy

Washington, D. C. 20585

Attention: C. McFarland

C. Carwile

M. Skalka

A. Jelacic

R. Toms

B. DiBona

R. R. Reeber

J. Salisbury

Department of Energy

(6)

Division of Fossil Fuel Extraction

Washington, D. C. 20585

Attention: E. P. Ferrero

J. Karhnak, Jr.

J. J. Stosur

J. Smith

R. Hertzberg

D. Crane

Department of Energy (2)

Division of Physical Research

Washington, D: C. 20585

Attention: G. A. Kolstad

D. K. Stevens

Defense Communication Agency

Washington, D. C. 20305

Attention: Maj. Lindsay, WSEO

Dresser Industries, Inc.

P. O. Box 6504

Houston, Texas 77005

Attention: Bill T. Greaves.

Roy M. Wolke

Lyman M. Edwards

$\mathrm{R}$. Ramage

Drilco Industrial

P. O. Box 3135

Midland, Texas 79701

Attention: Jack Kellner

Diamond Oil Well Drilling Co.

P. O. Box 6358 ATS

Midland, Texas 79701

Attention: J. Reynolds

A. Park 
Dresser Industries, Inc.

Security Division

P. O. Box 24647

Dallas, Texas 75224

Attention: M. Crow

W. Littman

Dyna-Drill (2)

Division of Smith International, Inc.

P. O. Box C-19576

Irvine, California 92713

Attention: K. H. Trzeciak

J. E. Tschirky

Department of Energy

Washington, D. C. 20585

Attention: J. T. Bartis, Acting Director

Division of Planning and Systems

Engineering, Room C-164

Dresser Industries, Inc.

Magcobar Division

P. O. Box 1407

Houston, Texas 77001

Attention: $J_{\cdot} \cdot K$. Bannerman

Dowell, Division of Dow Chemical, USA

P. O. Box 21

Tulsa, Oklahoma 74012

Attention: Lloyd Spangle

Department of Energy

Idaho Operations

550 second street

Headquarters Building, Room 119

Idaho Falis, Idaho 83401

Attention: S. Prestwich

Department of Energy (2)

San Francisco Operations office

1333 Broadway, Wells Fargo Building

Oakland, California 94612

Attention: A. Wilbur

T. Aducci 
Energy Systems, Inc.

4510 International Airport Road

Anchorage, Alaska 99502

Attention: William E. Ogle

Elf Aquitaine

Societe Nationale (Production)

26. Avenue Des Iilas

64000 Pau, France

Attention: Henri Clamens

Direction Production

Exxon Production Research Co.

P. O. Box 2189

Houston, Texas 77001

Attention: G. A. Loch

Albert T. Ellis

9459 La Jolla Farms Road

La Jolla, California 92037

$E G \& G$

P. O. Box 1625

Idaho Fal1s, Idaho 83401

Attention: Max R. Dolenc

Project Manager-Geoscience Stimulation

Energy Resources Exploration, Inc.

Geological Consulting

9720-D Candelaria, N. E.

Albuquerque, New Mexico 87112

Attention: P. R. (Bob) Grant, Jr., President

General Electric Company

P. O. Box 919

Bristol, Virginia 24201

Attention: R. W. Ojanen

General Electric Company 6325 Huntley Road

Worthington, Ohio 43085

(5)

Attention: M. D. Dennis

L. A. Offenbacher

W. H. Daniels

J.A. Salzer

E. J. Efsic 
Getty Oil Company

3903 Stoney Brook

Houston, Texas 77063

Attention: H. A. DeMirjian

Gulf Research and Development Co.

P. O. Drawer 2038

Pittsburgh, Pennsylvania 15230

Attention: Norman Coggeshall John C. Fair, Ph.D.

General Electric Company

P. 0 . Box 8, Building $\mathrm{K}-1$

Schenectady, New York 12301

Attention: L. E. Hibbs, Jr.

Geothermal Resources Council

P. O. Box 98

Davis, California 95616

Attention: D. N. Anderson

GTE Laboratories, Inc.

40 Sylvan Road

Waltham, Massachusetts 02154

Attention: D. R. Jelley, Supervisor Document Services

Geothermal Energy Institute

Box 1287

Natchez, Mississippi 39120

Attention: Dan Finn

Harry Diamond Laboratories

2800 Powder Mill Road

Adelphi, Maryland 20783

Attention: Stacey Gehman

Branch 13400

Halliburton Services (2)

P. O. Box 1431

Duncan, Oklahoma 73533

Attention: Mack Stogner

M. D. Misak

Hydril Company

3800 D. North Freeway.

Houston, Texas 77022

Attention: Jay Keithahn

Hydril

5005 Woodway

Houston, Texas 77056

Attention: John Greenip 
IMCO Services (2)
P. O. Box 22605
Houston, Texas 77027
Attention: Leroy Carney
Mario Zamora

Intercon Research Associates Ltd.

1219 Howard Street

Evanston, Illinois 60202

Attention: Rosemary D. Killermann

International Institute for Applied

Systems Analysis,

2361 Laxenburg

Austria

Attention: Dr. C. Marchetti

Livesay Consultants

2616 Angell

San Diego, California 92122

Attention: Dr. B. J. Livesay

Loffland Brothers Company

P. O. Box 2847

Tulsa, Oklahoma 74101

Attention: H. E. Mallory

Loffland Brothers Company

Four Corners Division

P. O. Box 3565

Grand Junction, Colórado 81501

Attention: G. Kemnitz, Jr.

Los Alamos Scientific Laboratory

Los Alamos, New Mexico 87544

Attention: John C. Rowley.

Bert R."Dannis

B. Hanold

Longyear Company

925 Delaware Street, GE

Minneapolis, Minnesota 55414

Attention: G. H. Beckley 6

Lawrence Berkeley Laboratory

Berkeley, California 94720

Attention: Dr. Marcelo Lippmann

W. Schwartz

Loffland Brothers Company.

8301 E. 51st Street

Tulsa, Oklahoma 74101

Attention: $w$. Koger 


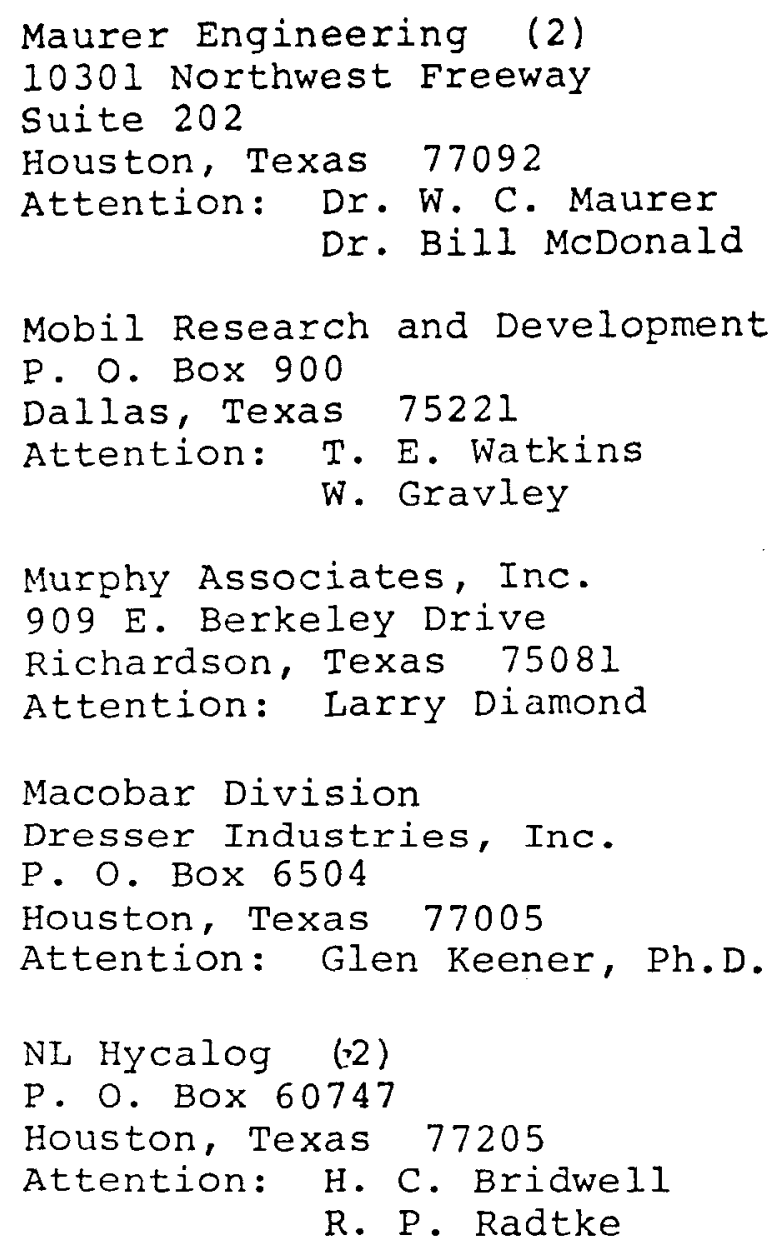

NL Petroleum Services

P. O. Box 1473

Houston, Texas 77001

Attention: J. Fontenot

B. Montgomery

OIL AND GAS JOURNAL

P. O. BOX 1260

Tulsa, Oklahoma 74101.

Attention: John L. Kennedy

Philips Petroleum Company 388 Frank Phillips Building Bartlesville, Oklahoma 74004 Attention: R. R. Angel

Phillips Petroleum Company 324 Frank Phillips Building Bartlesville, Oklahoma 74004 Attention: J. Whitmire 
Phillips Petroleum Company

(2)

P. O. Box 239

Salt Lake City, Utah 84110

Attention: Dr. C. W. Berge

Earl Hoff

Penn State University

Materials Research Lab

University Park, Pennsylvania 16802

Attention: Dr. Della M. RoY

Petroleum Information Corporation

National Geothermal Services

P. O. Box 2612

Denver, Colorado 80201

Progress Drilling, Inc.

4635 Sw Ereeway, Suite 620

Houston, Texas 77027

Attention: S. E. LOY, III

Republic Geothermal

11823 East Slauson, Suite 1

Santa Fe Springs, California 90670

Attention: Bob Rex

Rowan Drilling--U.S.

P. O. Box 2758

Midland, Texas 79702

Attention: W. J. Holbert

NL Hycalog (2)

P. O. Box 60747

Houston, Texas 77205

Attention: R. P. Radtke

H. C. Bridwell

Rotan Mosle, Inc.

2600 lst International Building

Dallas, Texas 75270

Attention: F. Mills

Reed Rock Bit Company

P. O. Box 2119

Houston, Texas 77001

Attention: B. Shoemaker 
Shell Development Company

(2)

P. O. Box 481

Houston, Texas 77001

Attention: C. L. Wickizer

E. B. Denison

Smith Tool Company

P. O. Box C-19511

Irvine, California 92713

Attention: J. Kingsolver

L. Garner

J. Vincent

Sun Gas Co.

P. O. Box 20

Dallas, Texas 75221

Attention: J. E. Zupanick

Shell Internationale Petroleum

Maatschappij B.V.

Exploration and Production

Carel van Bylandtlaan 30

The Hague, The Netherlands

Attention: B. E. Busking

Shell Exploratie en Produktie

Laboratorium/Koninklijke

Volmerlaan 6, Rijswijk

The Netherlands

Attention: R. Feenstra

Science Applications, Inc.

Chestnutt Ridge Professional Building

Morgantown, West Virginia. 26505

Attention: J. Pasini

Sperry-Sun Well Surveying Company

P. O. Box 36363

Houston, Texas 77036

Attention: Ed Blythe, Jr.

Tungsten Carbide Manufacturing' (2)

14451 Myford Road

Tustin, California 96280

Attention: D. Derthick, VP/General Manager

R. Housman, Manager, Technical Services

Tenneco Oil Company

P. O. Box 2511

Houston, Texas 77001

Attention: Dan Johnson 


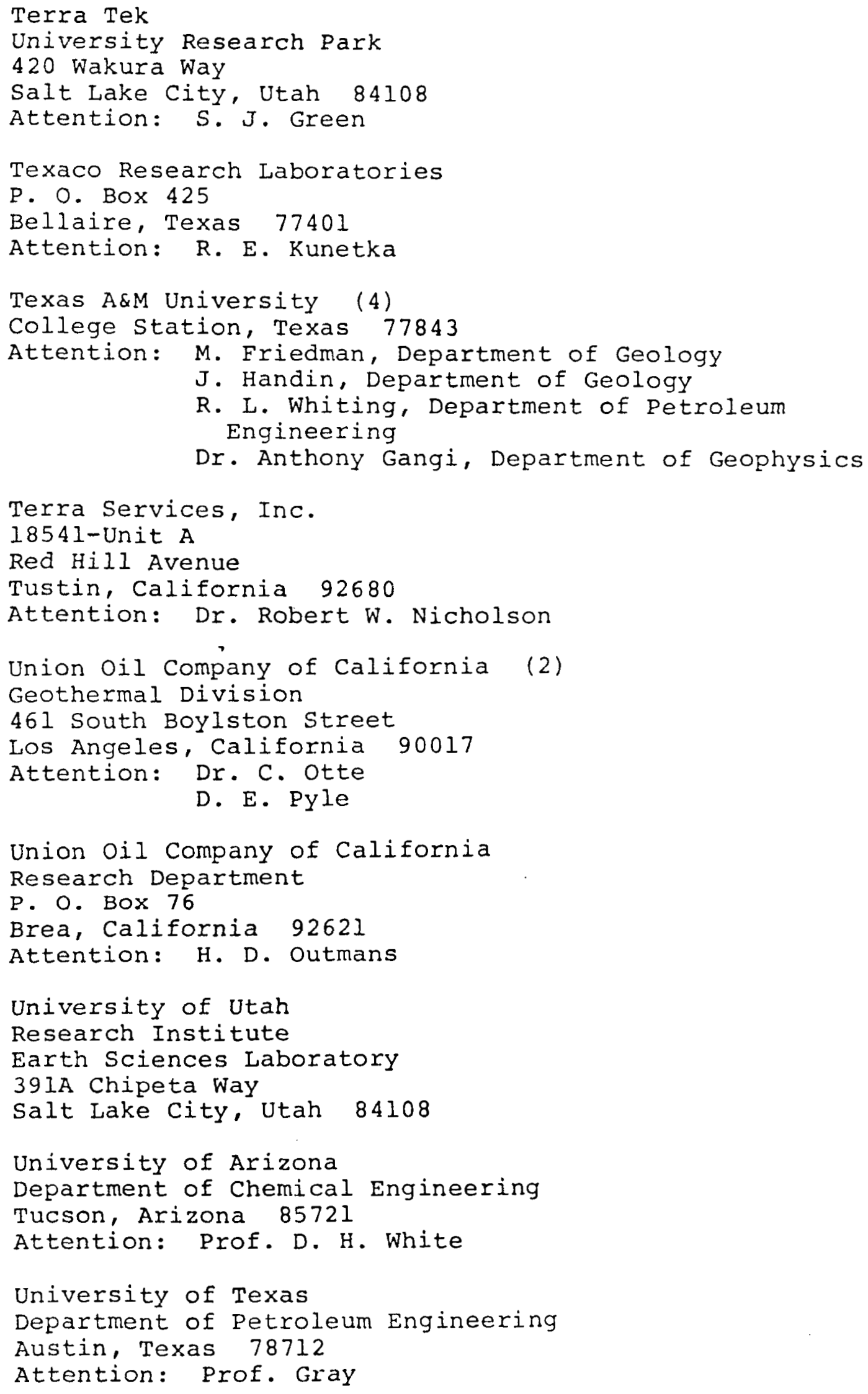


Union Oil Company of California

Union Geothermal Division

2099 Range Avenue

Santa Rosa, California 95406

Attention: Dr. Stephen Pye

Woodward-Clyde Associates

3 Embarcadero Center

San Francisco, California 94111

Attention: Ann Harrigan, Librarian

Wilson Downhole Services

P. O. Box 1492

Houston, Texas 77001

Attention: Don Hobbs

WKM Wellhead Systems

720 South Colorado Boulevard

suite 800

Denver, Colorado 80022

Attention: Allen Roberts

WORLD OIL MAGAZINE

P. O. BOX 2608

Houston, Texas 77001

Attention: Russel Wright

400

1000

C. Winter

1100

G. A. Fowler

1130

C. D. Broyles

2000

H. E. Viney

2300

E. D. Reed

2320

J. C. King

2325

2325

2328

2500

4000

4200

4300

400

4443

4500

4700

4710

4720

K. Gillespie

R. E. Fox

H. K. Togami

J. H. Barnette

J. C. Crawford

A. Narath

G. Yonas

R. L. Peurifoy, Jr.

A. W. Snyder

P. Yarrington

E. H. Beckner

J. H. Scott

4730

G. E. Brandvold

4740 R. K. Traeger

4741 S. G. Varnado

4741 T. E. Hinkebein

4741 D. L., Wesenberg

4742 . A. F. Veneruso 
4743

4744 H. M. Dodd

4744 J. Polito

5000 J. K. Galt

5512 A. Ortega

5530 W. Herrmann

5532 B. M. Butcher

5600 D. B. Schuster

5620 M. M. Newsom

5800 R. S. Claassen

ATTN: R. E. Whan - 5820

M. J. Davis - 5830
N. J. Magnani -5840

5810 R. G. Kepler

5811 L. A. Harrah

5812 C. J. Northrup

5812 B. T. Kenna

5813 J. G. Curro

5813 A. M. Kraynik

5813 P. B. Rand (3)

5831 N. J. Magnani

5832 R. W. Rohde

5833 J. L. Jellison

5834 D. M. Mattox

5835 C. H. Karnes

5836 J. L. Ledman

3141 T. L. Werner (5)

3151 W. L. Garner (3)

3172-3 R. P. Campbell (25)

(DOE/TIC)

8266 E. A. Aas (1) 